\title{
Analisa Proses Seleksi Operator pada PT. Dhanar Mas Concern Bandung
}

\author{
Hersa Dwi Yanuarso ${ }^{1}$, Rinda Gusvita ${ }^{1}$, Rohmah Helmikawaty ${ }^{2}$ \\ ${ }^{1}$ Prodi Teknik Industri \\ Institut Teknologi Sumatera, Kabupaten Lampung Selatan, 35365 \\ ${ }^{2}$ Prodi Psikologi \\ Universitas Jenderal Achmad Yani, Kotamadya Cimahi, 40531 \\ email: hersa.yanuarso@ti.itera.ac.id, rinda.gusvita@ti.itera.ac.id dan helmikawaty92@gmail.com \\ doi: https://doi.org/10.31315/opsi.v13i1.3472
}

Received: $12^{\text {th }}$ June 2020; Revised: $26^{\text {th }}$ June 2020; Accepted: $29^{\text {th }}$ June 2020;

Available online: $30^{\text {th }}$ June 2020; Published regularly: June 2020

\begin{abstract}
Employees or human resources are important assets in a company especially for textile industry. However, one of the important problems of the textile industry is the level of turnover. PT. Dhanar Mas Concern is an exportoriented textile company located in South Bandung which has a vision to be the best textile company with the most complete and best product in the world. In general, the person who controls these yarn and fabric making machine is called the operator (labor). The success of a company in managing the human resources is depend on the result of the selection process. So far the selection process for operators is carried out routinely every two times a week according to the needs of employees, due to hngh turnover rates. The high turnover rate is also a complaint of supervisors or team heads. The objective of the study is to determine how the selection process is conducted in textile company and the correlation between the the theory and the implementation in PT. Dhanar Mas Concern. The methodology research that used in this study is qualitative approach with descriptive research approach. This research shows that the selection process in PT. Dhanar Mas Concern met 7 (seven) of 8 (eight) stages which presented by William B. Werther Jr. and Keith Davis. The company overstepped the stage about interview with supervisors (user). The researcher suggests the company to implement the selection stages of interview with supervisors (user) cause the supervisor are the best informed of the technical aspects of the job. Supervisors interview may help to determine the extent of the applicants meet the company's employment requirements.
\end{abstract}

Keywords: Selection; Industrial Psychology; Human Resources Management and Operator.

\begin{abstract}
ABSTRAK
Karyawan atau sumber daya manusia merupakan asset penting dalam perusahaan khususnya bagi industri tekstil. Namun, salah satu masalah penting dari industri tektil (garment) adalah tingkat turnover. PT. Dhanar Mas Concern merupakan perusahaan tekstil berorientasi eksport yang berlokasi di Bandung Selatan yang memiliki visi untuk menjadi perusahaan tekstil terbaik dengan produk terlengkap di dunia. Secara umum, orang yang mengendalikan mesin-mesin pembuatan benang dan kain tersebut dinamakan operator. Keberhasilan suatu perusahaan dalam manajemen sumber daya manusia sangat tergantung pada hasil proses seleksi. Sejauh ini proses seleksi khusus untuk operator dilakukan secara rutin setiap dua kali dalam satu minggu sesuai permintaan kebutuhan karyawan dikarenakan angka turnover yang tinggi. Tingginya angka turnover juga menjadi keluhan para supervisor atau kepala regu. Oleh karen itu, tujuan penelitian ini adalah untuk mengetahui bagaimana proses seleksi operator PT. Dhanar Mas Concern dan kesesuaian antara teori dan pelaksanaan seleksi pada PT. Dhanar Mas Concern. Metodologi penelitian ini menggunakan pendekatan kualitatif deskriptif. Penelitian menunjukkan hasil bahwa proses seleksi di Industri Tekstil PT. Dhanar Mas Concern telah memenuhi 7 (tujuh) dari 8 (delapan) tahapan yang dikemukakan oleh William B. Werther Jr. dan Keith Davis dimana tahapan yang tidak dilakukan adalah wawancara dengan supervisor (user). Saran yang peneliti diajukan, sebaiknya perusahan tetap menerapkan tahapan seleksi wawancara dengan supervisor (user) mengingat seorang supervisor (user) dianggap paling mengetahui aspek teknis pekerjaan yang akan dilakukan. Sehingga penilaian dari supervisor bisa membantu memastikan sejauh mana pelamar sesuai dengan persyaratan kerja di perusahaan.
\end{abstract}

Kata Kunci: Seleksi; Psikologi Industri; Sumber Daya Manusia dan Operator 


\section{PENDAHULUAN}

Bagi suatu perusahaan, sumber daya manusia (SDM) atau biasa disebut dengan karyawan adalah asset yang penting dan unik diantara aset-aset lain seperti modal, bangunan, mesin, peralatan kantor, persediaan barang, dan lainnya. Hanya karyawan yang dapat bernapas, berpikir dan berperilaku. Keunikan ini akan memberikan sumbangan yang besar jika memilki kualitas yang baik dan dilibatkan dalam aktivitas perusahaan guna kemajuan perusahaan (Rahmawati dan Shalahuddin, 2017).

PT. Dhanar Mas Concern (PT. DMC) merupakan perusahaan tekstil berlokasi di Bandung Selatan dan berorientasi eksport yang memiliki visi untuk menjadi perusahaan tekstil (garment) terbaik dengan produk terlengkap di Dunia. Perusahaan ini telah berdiri sejak tahun 1964. Hingga saat ini, PT. DMC sudah memiliki empat buah pabrik yaitu di Cisirung, dua di Banjaran dan satu di Ujung Berung. Unit produksi spinning berhubungan dengan penyediaan kapas alami baik lokal maupun impor dan menghasilkan benang. Sedangkan unit produksi weaving menghasilkan kain mentah yang diolah dari benang yang dihasilkan dari unit produksi spinning. Secara umum, mesin-mesin pembuatan benang dan kain tersebut dikerjakan oleh operator atau buruh.

Dengan adanya empat buah pabrik yang dimiliki oleh PT. DMC dibutuhkan karyawan yang tidak sedikit untuk memenuhi kebutuhan akan staff dan unit-unit produksi disana. Pada saat penelitian ini disusun, PT. DMC sedang membutuhkan karyawan untuk menduduki posisi sebagai Kabag GA \& Personalia (KGP), Staff Logistik (SL), Purchasing (SP), Accounting \& Finance (ACC \& FIN), dan Staff Safety and Healthy (SHE). Selain kebutuhan akan staff, sebagai pabrik pembuat kain setengah jadi, PT. DMC juga membutuhkan para operator atau buruh. Sebagai industri yang tombak utamanya ada produksi kain, pemenuhan operator menjadi hal yang penting. Seorang operator memerlukan keahlian dan kecakapan yang tinggi bekerja dengan mesin, maka tidak sembarang orang dapat menjadi operator, diperlukan seleksi yang ketat untuk mendapatkan operator yang sesuai.

Namun, salah satu masalah penting bagi perusahaan tekstil (garment) adalah tingkat turnover karyawan. Price (1997) yang mengklasifikasikan tingkat turnover menurut jenis organisasi, untuk 53 studi pada tahun 1947 sampai dengan 1971 menemukan bahwa industri manufaktur memiliki tingkat perputaran karyawan dengan rata-rata tertinggi (Putranti dan Suparmi, 2017). Di Indonesia masalah turnover di perusahaan tekstil juga menjadi perhatian penting (Sidharta dan Margaretha, 2011, Waspodo, Handayani, dan Paramita, 2013, Carolina, 2012, Palupi, 2011). Pergantian karyawan (turnover) bukanlah konsep yang relatif baru dalam manajemen, tetapi masalah yang khas dalam sumber daya manusia dan menarik perhatian administrasi publik dan manajemen industri dan praktisi dunia (Mbah, 2012).

Keberhasilan bagi suatu perusahaan salah satunya bergantung pada upaya perusahaan untuk memperoleh dan menempatkan karyawan yang sesuai dengan keahlian dan kebutuhannya. Sehingga penting bagi perusahaan untuk melakukan seleksi bagi calon karyawan. Dari hasil penyeleksian yang baik dapat menentukan calon karyawan diterima atau ditolak. Tidak jarang, perusahaan harus mengeluarkan biaya ekstra untuk melakukan pererutan, seleksi dan pelatihan karyawan baru. Berdasarkan hasil wawancara awal, prosedur seleksi khusus untuk operator PT. DMC sudah menjadi kegiatan rutin yang dilaksanakan setiap dua kali dalam satu minggu. Hal tersebut bertujuan untuk memenuhi standar kualitas sumber daya manusianya dan memenuhi kebutuhan operator yang sering keluar masuk (turnover). Keluar masuknya karyawan operator (buruh) yang tinggi pun menimbulkan keluhan dari setiap supervisor atau kepala regu yang menjadi atasan para operator karena mereka harus terus melatih ulang operator baru, yang tidak hanya melelahkan secara fisik dan mental tetapi juga merugikan secara waktu.

Werther dan Davis (1996) mendefinisikan seleksi sebagai proses memilih individu untuk mengisi tawaran pekerjaan yang tersedia sesuai dengan kualifikasi-kualifikasi yang telah ditetapkan. Pentingnya seleksi mengakibatkan kegiatan tersebut harus dilakukan secara tepat dan benar untuk mendapatkan tenaga kerja yang dibutuhkan. Oleh sebab itu, kegiatan seleksi calon karyawan perlu dilaksanakan dan terselenggara sesuai dengan aturan dan tahapan proses seleksi perusahaan guna meningkatkan keberhasilan perusahaan dalam mengelola sumber daya manusia atau karyawan.

Berdasarkan latar belakang tersebut, peneliti 
memutuskan untuk melakukan Analisa proses seleksi dengan tujuan sebagai berikut: (1) untuk mengetahui bagaimana proses seleksi pada operator Insustri Textil PT. Dhanar Mas Concern, (2) untuk mengetahui kesesuaian antara teori dan pelaksanaan seleksi pada PT. Dhanar Mas Concern.

\section{STUDI LITERATUR}

\subsection{Definisi Seleksi}

Seleksi menurut pandangan Werther \& Davis (1996) adalah proses bertahap untuk memperoleh dan memanfaatkan berbagai informasi mengenai para pelamar kerja guna menentukan siapa saja yang akan ditarik sebagai karyawan untuk mengisi lowongan posisi-posisi jangka panjang maupun jangka pendek. Werther \& Davis juga menambahkan bahwa seleksi adalah proses memilih individu untuk mengisi tawaran pekerjaan yang tersedia seusi dengan kualifikasi-kualifikasi yang telah ditetapkan. Hariandja (2002) mengungkapkan seleksi didefinisikan sebagai suatu proses berkelanjutan setelah kegiatan rekrutmen, baik yang rekrutmen internal maupun eksternal guna memutuskan pegawai yang dari sekumpulan calon pegawai. Seleksi merupakan kegiatan yang sangat penting karena hasil dari kegiatan rekrutmen belum menjamin didapatkannya calon pegawai yang sesuai dengan perusahaan. Proses seleksi tidak hanya memilih pergawai yang seusi dari sudut pandang perusahaan, tetapi juga dari sudut pandang calon pegawai itu sendiri.

Dalam praktiknya, proses seleksi tidak hanya dapat dimanfaatkan untuk memperoleh karyawan baru tetapi bisa juga digunakan untuk kegiatan promosi jabatan, rotasi jabatan dan Langkah terakhir sebelum pemutusan hubungan kerja dengan perusahaan. Pada prinsipnya kegitan ini berkaitan dengan tahaptahap atau proses tertentu.

Berkaitan dengan proses dan tahapan seleksi Werther dan Davis (dalam Hariandja, 2002) mengemukakan bahwa: the selection process is a series of specific steps used to decide which recruits should be hired. A typical set steps are preliminary reception of application, employee test, selection interview, referent and background check, medical evaluation, supervisor interview, realistic job preview and hiring decision. Melalui proses seleksi diharapkan individu yang memiliki kualifikasi yang sesuai dengan pekerjaan yang tersedia saja yang lolos untuk bekerja. Serangkaian proses seleksi tersebut adalah:

Tahap 1: Preliminary reception of application (penerimaan pendahuluan)

Proses penerimaan pendahuluan adalah ketika calon diminta mendatangi perusahaan. Tahap ini berfungsi bagi masing-masing pihak, yaitu pelamar dan perusahaan, untuk saling melengkapi informasi yang dilakukan melalui wawancara. Bagi pelamar berfungsi untuk mengetahui informasi lebih jauh mengenai perusahaan yang ia lamar merupakan pilihannya. Sedangkan bagi perusahaan, seleksi menjadi proses menyaring calon karyawan yang sesuai dengan kriteria perusahaan.

Tahap 2: Employee test (ujian penerimaan pelamar)

Ujian penerimaan merupakan salah satu teknik yang digunakan dalam proses seleksi. Ujian ini dapat berbentuk tes tertulis maupun parktik. Ujian ini bertujuan untuk mengetahui sejauh mana kemampuan calon karyawan dengan pekerjaan di perusahaan nanti. Jenis tes yang dipilih disesuaikan dengan kebutuhan dari setiap perusahaan dan disesuaikan dengan persyaratan kerja (job related).

Tahap 3: Selection interview (wawancara seleksi)

Wawancara merupakan tahapan seleksi yang paling sering dilaksanakan oleh perusahaan dibandingkan tes tertulis. Teknik wawancara yang digunakan dalam prosedur seleksi tenaga kerja oleh Minner (1992) dibedakan kedalam tiga jenis teknik, yaitu: teknik wawancara berpola atau berstruktur, teknik wawancara tidak mengarah (non directive interview) dan teknik wawancara ganda (Munandar, 2008).

Tahap 4: Referent and background check (pemeriksaan latar belakang dan referensi)

Pengalaman bekerja, keikutsertaan dalam kegiatan sosial, pengalaman berorganisasi merupakan hal yang dapat digali untuk ngetahui latar belakang calon karyawan. Sedangkan pemeriksaan referensi adalah pemeriksaan surat referensi yang dilampirkan oleh calon karyawan meliputi surat paklaring dari pekerjaan sebelumnya, surat referensi dari universitas dan lain sebagainya. Hal ini bertujuan untuk mengetahui kebenaran data yang diberikan sebagai bahan pertimbangan kecapakan atau kualitas calon karyawan. 
Tahap 5: Medical evaluation (evaluasi kesehatan)

Faktor kesehatan menjadi hal yang penting sebagai pertimbangan dalam menerima calon karyawan karena akan berpengaruh terhadap produktifitas karyawan dan biaya yang perlu ditanggung oleh perusahaan terkait pemeliharaan kesehatan karyawan. Informasi mengenai kesehatan calon karyawan dapat dilakukan dengan menanyakan tentang Riwayat penyakit dan pemerikasaan umum kesehatan di klinik perusahaan untuk hasil yang lebih akurat. Biasanya biaya akan dibebankan pada perusahaan.

Tahap 6: Supervisor interview (wawancara supervisor atau $u$ ser)

Wawancara dengan supervisor atau user (atasan langsung) merupakan hal yang sangat penting untuk memastikan sejauh mana pelamar sesuai dengan persyaratan kerja yang diinginkan karena mereka adalah orang yang paling mengetahui aspek teknis terkait pekerjaan yang tersedia.

Tahap 7: Realistic job preview (penjelasan pekerjaan secara realistis)

Dalam tahap ini, pihak perusahaan memberikan memberikan gambaran atau penjelasan mengenai pekerjaan yang akan dikerjakan (realistis). Penjelasan tersebut meliputi besaran gaji, jam kerja, beban kerja dan budaya organisasi. Hal ini perlu dilakukan untuk menghindari ekspektasi berlebih dari karyawan terhadap perusahaan maupun sebaliknya.

Tahap 8: Hiring decision (keputusan penerimaan)

Keputusan penerimaan dapat diberikan oleh atasan langsung atau departemen rekrutmen sesuai kebijakan perusahaan. Tahapan ini sekaligus menjadi tadapan terakhir dalam proses seleksi karyawan.

Serangkaian proses seleksi yang telah dijelaskan diatas tidaklah merupakan harga mati, misalnya dengan mengatakan bahwa seleksi yang tidak mengikuti prosedur tersebut tidaklah valid atau job related (sesuai dengan persyaratan kerja). Dimana prosedur seleksi diatas hanya sebagai pedoman atau kerangka dasar/umum yang dapat dipertimbangkan dan disesuaikan dengan situasi organisasi, sumber calon dan persyaratan jabatan (Hariandja, 2002).

\subsection{Indikator Penelitian}

Proses seleksi dilakukan dengan melihat bagaimana PT. Dhanar Mas Concern melaksanakan kegiatan seleksi yang ada, dengan berlandaskan pada teori menurut Werther dan Davis serta diturunkan menjadi tahapan-tahapan maka indikatornya yang didapat adalah sebagai berikut:

Tabel 1. Indikator proses seleksi

\begin{tabular}{|c|c|c|}
\hline Variabel & Tahapan & Indikator \\
\hline \multirow[t]{5}{*}{$\begin{array}{l}\text { Tahapan } \\
\text { dalam } \\
\text { proses } \\
\text { seleksi }\end{array}$} & $\begin{array}{l}\text { Penerimaan } \\
\text { pendahuluan }\end{array}$ & $\begin{array}{l}\text { - Pelamar datang ke } \\
\text { perusahaan } \\
\text { membawa berkas } \\
\text { lamaran. } \\
\text { - Adanya } \\
\text { pertukaran } \\
\text { informasi antara } \\
\text { peamar dan } \\
\text { perusahaan. }\end{array}$ \\
\hline & $\begin{array}{l}\text { Ujian } \\
\text { penerimaan } \\
\text { pegawai }\end{array}$ & $\begin{array}{l}\text { - Perusahaan } \\
\text { memberikan tes } \\
\text { psikologi kepada } \\
\text { calon pegawai. } \\
\text { - Perusahaan } \\
\text { memberikan tes } \\
\text { tertulis kepada } \\
\text { calon pegawai. } \\
\text { - Perusahaan } \\
\text { memberikan tes } \\
\text { praktek kepada } \\
\text { calon pegawai. }\end{array}$ \\
\hline & $\begin{array}{l}\text { Wawancara } \\
\text { seleksi }\end{array}$ & \begin{tabular}{lr}
\multicolumn{2}{l}{ Perusahaan } \\
melakukan & seleksi \\
berupa & wawancara \\
kepada & calon \\
pelamar &
\end{tabular} \\
\hline & $\begin{array}{l}\text { Pemeriksaan } \\
\text { latar belakang } \\
\text { dan referensi }\end{array}$ & 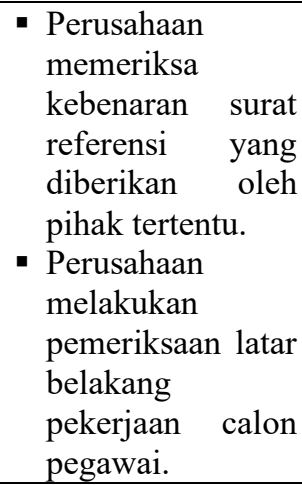 \\
\hline & $\begin{array}{l}\text { Penilaian tes } \\
\text { kesehatan }\end{array}$ & $\begin{array}{l}\text { - Perusahaan } \\
\text { menanyakan } \\
\text { kondisi kesehatan } \\
\text { umum calon } \\
\text { pegawai, } \\
\text { misalnya } \\
\text { penyakit yang } \\
\text { sering dialami, } \\
\text { berapa kali sering } \\
\text { ke rumah sakit, } \\
\text { dll. }\end{array}$ \\
\hline
\end{tabular}


- Pelamar

melakukan

pemeriksaan

kesehatan

di

klinik

perusahaan.

\begin{tabular}{ll}
\hline Wawancara & Supervisor \\
dengan & melakukan \\
supervisor & wawancara kepada \\
& pelamar.
\end{tabular}

$\begin{array}{ll}\text { Penjelasan } & \text { Perusahaan } \\ \text { pekerjaan } & \text { memberikan } \\ \text { secara realistis } & \text { infomasi meliputi } \\ & \text { gaji, beban kerja, } \\ & \text { jam kerja, dan } \\ & \text { sebagainya kepada } \\ & \text { pelamar. }\end{array}$

$\begin{array}{ll}\text { Keputusan } & \text { - } \\ \text { penerimaan } & \text { memberikan } \\ & \text { pemberitahuan } \\ & \text { diterima kepada } \\ & \text { calon pegawai. } \\ & \text { - Perusahaan } \\ & \text { memberikan } \\ & \text { pemberitahuan } \\ & \text { tidak diterima } \\ & \text { kepada calon } \\ & \text { pegawai. } \\ & \end{array}$

\section{METODOLOGI PENELITIAN}

Berdasarkan tujuan penelitian, peneliti menggunakan metode kualitatif dengan pendekatan penelitian deskriptif. Sugiono (2017:35) mengungkapkan bahwa metode penelitian deskriptif dilakukan untuk mengetahui keberadaan suatu variable mandiri, baik pada satu variabel atau lebih (variabel bebas) tanpa membuat perbandingan variabel atau mencari hubungan dengan variabel lain.

Sumber data yang digunakan yaitu sumber primer dan sumber sekunder. (Sugiono, 2016). Sumber primer adalah sekumpulan data yang menjadi data utama bagi peneliti yang didapatkan secara langsung oleh peneliti. Sedangkan sumber sekunder adalah sekumpulan data yang yang tidak langsung diperoleh oleh peneliti, misalnya melalui orang lain atau dokumen dan merupakan data pelengkap. Dilihat dari segi cara atau teknik pengumpulan data, teknik pengumpulan data dilakukan oleh peneliti adalah wawancara, observasi dan kajian dokumen.

Data primer yang didapatkan mengenai proses seleksi pada PT. Dhanar Mas Concern ini didapatkan melalui wawancara dan observasi kepada bagian Training \& Development, yaitu bagian Rekrutmen. Sedangkan observasi yang dilakukan Sedangkan data sekunder diperoleh dari kajian dokumen berupa arsip perusahaan seperti syarat calon karyawan, profil perusahaan, visi dan misi perusahaan, struktur organisasi, serta prosedur proses rekrutmen dan seleksi.

Hasil dari proses wawancara berupa data verbatim yang kemudian di tarik kesimpulannya. Sedangkan Observasi dan daily record dijabarkan secara tertulis untuk selanjutnya diambil kesimpulannya. Jenis observasi yang dilakukan oleh peneliti adalah observasi partisipatif, dimana peneliti terlibat dengan kegiatan sehari-hari informan/sumber data yang sedang diamati/digunakan. Kemudian data yang telah dikumpulkan dianalisa dalam tiga tahap meliputi reduksi data (data reduction), penyajian data (data display), serta penarikan kesimpulan dan verifikasi (conclusion drawing/verification) untuk mendapatkan hasil dan simpulan penelitian.

\section{HASIL DAN PEMBAHASAN}

Seleksi adalah proses memilih individu untuk mengisi tawaran pekerjaan yang tersedia sesuai dengan kualifikasi-kualifikasi yang telah ditetapkan untuk mengisi kebutuhan sumber daya manusia di perusahaan. Tujuan dilakukannya seleksi adalah untuk mendapatkan seorang atau sejumlah orang yang sesuai dengan kualifikasi pekerjaan untuk di terima bekerja di suatu perusahaan. Dari data yang diperoleh dilapangan yaitu proses seleksi calon operator di PT. Dhanar Mas Concern pada umumnya telah sesuai dengan tahapan seleksi Werther dan Davis. Namun masih terdapat beberapa perbedan dalam penempatan atau tata cara pelaksanaannya.

Seleksi yang dilakukan di PT. Dhanar Mas Concern bertujuan untuk mendapatkan pegawai yang tepat sesuai dengan kualifikasi pekerjannya yaitu sebagai operator/buruh pabrik. Penyeleksian dilakukan oleh bagian Rekrutmen dibantu oleh trainer dan atasan langsung di departemen Training and Development untuk melakukan seleksi calon pegawai.

Berdasarkan analisa dan kajian data wawancara, observasi dan kajian dokumen didapatkan bahwa secara terstruktur, tahapan 
poses seleksi yang dilakukan di PT. Dhanar Mas Concern terbagi menjadi 5 (lima) tahap, namun kegiatannya sudah mencakup 7 (tujuh) dari 8 (delapan) tahapan seleksi Werther dan Davis seperti yang terlihat pada Tabel 2 dibawah ini.

Tabel 2. Analisa proses seleksi operator PT. Dhanar Mas Concern

\begin{tabular}{|c|c|c|}
\hline Tahap & $\begin{array}{l}\text { Werther } \\
\text { \& Davis }\end{array}$ & PT. DMC \\
\hline Tahap 1 & $\begin{array}{l}\text { Penerimaan } \\
\text { Pendahuluan }\end{array}$ & $\begin{array}{l}\text { Seleksi } \\
\text { Administrasi }\end{array}$ \\
\hline Tahap 2 & $\begin{array}{l}\text { Ujian } \\
\text { Penerimaan }\end{array}$ & $\begin{array}{l}\text { Tes Psikologi } \\
\text { Tes Fisik } \\
\text { Tes Tertulis } \\
\text { Wawancara } \\
\text { Penjelasan } \\
\text { Pekerjaan }\end{array}$ \\
\hline Tahap 3 & Wawancara & $\begin{array}{l}\text { Tes Lapangan } \\
\text { (Training) }\end{array}$ \\
\hline Tahap 4 & $\begin{array}{l}\text { Pemeriksaan } \\
\text { Latar } \\
\text { Belakang \& } \\
\text { Referensi }\end{array}$ & Tes Kesehatan \\
\hline Tahap 5 & Tes Kesehatan & $\begin{array}{l}\text { Keputusan } \\
\text { Penerimaan }\end{array}$ \\
\hline Tahap 6 & $\begin{array}{l}\text { Wawancara } \\
\text { supervisor } \\
(\text { user })^{*}\end{array}$ & \\
\hline Tahap 7 & $\begin{array}{l}\text { Penjelasan } \\
\text { Pekerjaan }\end{array}$ & \\
\hline Tahap 8 & $\begin{array}{l}\text { Keputusan } \\
\text { Penerimaan }\end{array}$ & \\
\hline
\end{tabular}

Sumber: Bagian Rekrutmen PT. Dhanar Mas Concern

Berdasarkan tabel di atas, berikut penjelasan masing-masing tahapan, antara lain:

Tahap 1: Seleksi Administrasi

Screening persayatan administratif berupa berkas lamaran fisik, meliputi: usia, jenis kelamin, tinggi badan, pendidikan terakhir dan pengalaman kerja. Untuk menempati posisi operator/buruh pabrik diutamakan seorang wanita. Hal ini dikarenakan berdasarkan riset Tim Rekrutmen, wanita khususnya ibu memiliki karakteristik tidak mudah bosan mengerjakan pekerjaan rutin \& monoton serta dalam kondisi yang memerlukan pekerjaan, Sehingga kemungkinan untuk bertahan di perusahaan tinggi, untuk mengurangi keluar masuknya (turnover) pekerja.

Tahap 2: Tes Psikologi, Tes Fisik, Tes Tertulis dan Wawancara
Keseluruhan tes ini dilaksanakan dalam satu hari kerja, dengan urutan sebagai berikut:

a. Tes Psikologi: Army Beta (bertujuan untuk mengetahui daya tangkap pelamar) dan TIU 5 (bertujuan untuk mengetahui tingkat kecerdasan pelamar).

b. Tes tertulis mengenai pengetahuan umum mesin atau listrik sesuai dengan pendidikan pelamar.

c. Tes fisik meliputi tinggi dan berat badan.

d. Wawancara oleh staf rekrutmen yang dilakukan berkelompok per 5 (lima) orang. Proses ini bertujuan untuk melakukan verifikasi identitas pelamar, meliputi identitas pribadi, keluarga, pendidikan, pengalaman bekerja, dan penyakit yang diderita. Selain itu wawancara juga berfungsi sebagai seleksi pelamar untuk menemukan calon operator yang serius dan sesuai dengan kebutuhan user.

Pengumuman lolos tes tahap 2 diberitahukan melalui telepon, dengan menyampaikan penjelasan pekerjaan meliputi jenis pekerjaan, tugas pokok, gaji, jam kerja, dan tunjangan lainnya, serta aturan mengikuti tes lapangan (training).

\section{Tahap 3: Tes Lapangan (Training)}

Bertujuan sebagai pembekalan untuk para pelamar mengenai pekerjaan dan rutinitas yang akan mereka lakukan di perusahaan. Tes lapangan ini biasanya berlangsung selama 1-2 hari dari jam 08.00-12.00 yang akan dilaksanakan oleh bagian training.

Tahap 4: Tes Kesehatan

Tes kesehatan ini meliputi rontgen dan tes buta warna dengan biaya sebesar Rp. 95.000. Pelamar juga diharapkan tidak memiliki riwayat penyakit darah tinggi.

Tahap 5: Keputusan Penerimaan

Pelamar yang diterima sebagai operator akan dihubungi oleh Tim Rekrutmen dan diminta melengkapi data meliputi Surat Keterangan Kelakuan Baik dan foto copy buku rekening.

PT. Dhanar Mas Concern telah mengaplikasikan tahapan proses seleksi yang sudah diadaptasi dengan kebutuhan perusahaan. Dalam wawancara disampaikan bahwa proses seleksi tahap 2, yaitu ujian penerimaan untuk calon operator secara rutin dilakukan dua kali dalam seminggu. Hal tersebut dikarenakan tim Rekrutmen 
diharuskan memenuhu tuntutan ketersediaan tenaga kerja kurang lebih atau sama dengan 14 (empat belas) hari kerja. Selain itu dalam sekali ujian penerimaan belum tentu didapatkan operator yang sesuai. Oleh karena itu tahapan seleksi di padatkan menjadi 5 (lima) tahapan.

Terdapat satu tahapan yang tidak dilakukan untuk menjaring calon operator, yaitu wawancara dengan supervisor atau user. Tahapan ini hanya dilakukan untuk menjaring calon staf saja. Hal tersebut dilakukan karena Tim Rekrutmen diharapkan sudah memahami kebutuhan user yang sudah disampaikan dalam SPTK (Surat Permohonan Tenaga Kerja).

Menurut Hariandja (2002) prosedur seleksi diatas tidaklah merupakan harga mati, misalnya dengan mengatakan bahwa seleksi yang tidak mengikuti prosedur tersebut tidaklah valid atau job related (sesuai dengan persyaratan kerja). Prosedur seleksi diatas hanya sebagai pedoman atau kerangka dasar/umum yang dapat dipertimbangkan dan disesuaikan dengan situasi organisasi, sumber calon dan persyaratan jabatan.

\section{KESIMPULAN DAN SARAN}

Berdasarkan hasil analisa dan pembahasan yang telah dipaparkan sebelumnya, proses seleksi yang dilakukan di PT. Dhanar Mas Concern secara terstruktur memiliki beberapa perbedaan dengan proses seleksi yang dikemukakan oleh William B. Werther Jr. dan Keith Davis. Secara terstruktur PT. Dhanar Mas Concern melaksanakan 5 (lima) tahap seleksi dari 8 (delapan) tahapan yang terdapat dalam teori. Kelima tahapan itu adalah seleksi administrasi, ujian penerimaan pegawai (tes psikotes, tes tertulis, tes fisik, dan wawancara), tes lapangan/training dan tes kesehatan. Namun dalam pelaksanaannya, kegiatan seleksi yang dilakukan mencakup tujuh dari delapan tahapan seleksi William B. Werther Jr. dan Keith Davis. Dimana proses wawancara dan penjelasan pekerjaan dilakukan saat seleksi tahap kedua besamaan dengan ujian penerimaan.

Terdapat satu tahapan yang tidak dilakukan untuk seleksi operator yaitu wawancara supervisor (user). Oleh karena itu, proses seleksi yang dilakukan di PT. Dhanar Mas Concern dapat dikatakan sudah mendekati atau sesuai dengan teori seleksi William B. Werther Jr. dan Keith Davis.

Saran yang dapat direkomendasikan untuk PT. Dhanar Mas Concern adalah sebaiknya perusahan tetap menerapkan tahapan seleksi wawancara dengan supervisor (user) mengingat seorang supervisor (user) adalah orang paling mengetahui aspek teknis pekerjaan terbeut. Penilaian dari supervisor (user) dapat membantu memastikan sejauh mana kesesuaian antara kualifikasi pekerjaan dengan kualitas calon karyawan yang mengikuti seleksi. Diharapkan dengan melaksanakan tahapan ini tingkat turnover operator juga dapat berkurang.

\section{DAFTAR PUSTAKA}

Carolina, Y. A. (2012). Pengaruh Iklim Etika Terhadap Komitmen Organisasi dan Turnover Intention (Studi Kasus: PT Trac Cikarang).

Hariandja, M. T. E. (2002). Manajemen sumber daya manusia. Grasindo.

Mbah, S. E., \& Ifeanyi, I. I. (2012). Consensus Building: Implications for LabourManagement Relations in Nigeria. J. Mgmt. \& Sustainability, 2, 190.

Miner, J. B. (1992). Industrial-organizational psychology. McGraw-Hill Book Company.

Munandar, Ashar Sunyoto, 2008, Psikologi Industri dan Organisasi, Penerbitan Universitas Indonesia (UI-Press), Jakarta.

Palupi, D. A. P. (2011). Memprediksikan Turnover Pada Karyawan Perusahaan Garmen: Pengaruh Praktek Pengembangan Sumber Daya Manusia dan Kepercayaan Terhadap Organisasi. Jurnal Ilmu Manajemen dan Akuntansi Terapan (JIMAT), 2(2).

Price, J. L. (1977). The study of turnover. Iowa State Press.

Putranti, R. D. (2016). Pengembangan Model Kepemimpinan Path Goal Pada Supervisor Garment Dalam Mengelola Turnover Intention Di Kecamatan Klari Kabupaten Karawang. Media Ekonomi dan Manajemen, 31(1).

Rahmawati, S., \& Shalahuddin, S. (2017). Proses Seleksi Karyawan Baru Bagian Sales Pada PT Mitra Sukses Karya Bersama Bekasi. Jurnal Administrasi Kantor, 5(1), 99-106.

Sidharta, N., \& Margaretha, M. (2011). Dampak komitmen organisasi dan kepuasan kerja terhadap turnover intention: studi empiris pada karyawan bagian operator di salah satu perusahaan garment di Cimahi. 
Jurnal Manajemen, 10(2), 129-142.

Sugiono, S. (2016). Metode Penelitian

Kuantitatif, Kualitatif, dan R \& D. Bandung: Alfabeta.

Waspodo, A. A., Handayani, N. C., \& Paramita, W. (2013). Pengaruh kepuasan kerja dan stres kerja terhadap turnover intention pada karyawan pt. Unitex di bogor. JRMSI-Jurnal Riset Manajemen Sains Indonesia, 4(1), 97115.

Werther, W. B., \& Davis, K. (1989). Human resources and personnel management. Harper San Francisco. 